\title{
DRUGS LAW AND LEGAL PRACTICE IN SOUTHEAST ASIA: INDONESIA, SINGAPORE, AND VIETNAM
}

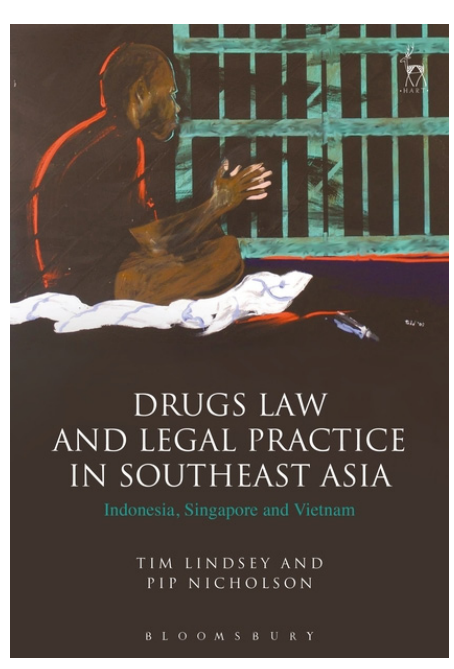

Drugs Law and Legal Practice in Southeast Asia investigates criminal law and practice relevant to drugs regulation in three Southeast Asian jurisdictions: Indonesia, Singapore and Vietnam. These jurisdictions represent the spectrum of approaches to drugs regulation in Southeast Asia, highlighting differences in practice between civil and common law countries, and between liberal and authoritarian states.

This book is divided into five chapters. The first chapteroffers an account of criminal law and practice relevant to drugs regulation in three Southeast Asian jurisdictions: Indonesia, Singapore and Vietnam. The core of the book comprises three country studies based on extensive fieldwork, each offering original analysis of criminal law and procedure in drugs regulation in three very different Southeast Asian states. We approach each country by examining, in turn, investigation, trial, and sentencing. The last category also includes the death penalty, as well as the different mechanisms available for pardon and clemency. In short, we frame our analysis to reflect how a defendant prosecuted for drugs offences is treated in each jurisdiction, in a loosely sequential order.

Although their legal systems are very different, the three countries selected for investigation share a commitment to the current international drugs law regime. This is based on three major United Nations (UN) conventions to which each is a signatory: the UN Single Convention on Narcotic Drugs, 1961 (as amended by the Protocol of 1972); the UN Convention on Psychotropic Substances, 1971; and the UN Convention against the Illicit Traffic in Narcotic Drugs and Psychotropic Substances, 1988. The next chapter offers a brief overview of these conventions and the international system for regulation of drugs they establish. An indicative summary of the extent to which Indonesia, Singapore and Vietnam have met their obligations under the Conventions in their domestic laws appears in an appendix at the end of the book.

Second chapter offers an overview of the three major conventions, including their origins and key features. It closes with a short summary of institutions relevant to regional co-operation on drugs in Southeast Asia. The country studies in this book show that the drugs law regimes of Indonesia, Singapore and Vietnam are different in many ways. The legislation of the three countries follows very different models and their courts have procedures that sometimes have very little in common. The outcomes of drugs prosecutions also often vary dramatically, as is shown later in this book. The three countries do, however, share a commitment to the current international drugs law regime. This is based around the three major United Nations conventions to which each is a signatory. They are also participants in regional organizations designed to facilitate co-operation between Southeast Asian states to prevent the illicit use of drugs. 
The third chapter presents an overview of the laws and institutional arrangements for the regulation of narcotics within Indonesia. It draws from a range of sources including legislation, cases, official policy documents, reports, media articles, government statistics and academic analysis. The first section offers a brief summary of the history of the narcotics trade in Indonesia, as well as current drug use and state responses to it. The next section describes the main drug-related offences under Indonesian law and the elements of criminal responsibility. The third section considers jurisdictional issues in relation to drug-related offences. The fourth section describes criminal procedure for drugs crimes from arrest to trial, paying particular attention to the relevant sections of Indonesia's Criminal Procedure Code (Kitab Undang- undang Hukum Acara Pidana, KUHAP). The fifth section examines the rights of the accused during the investigation process, while the sixth section examines trial and sentencing. The seventh section details Indonesia's approach to rehabilitation of drugs users, a growing area of concern for the Indonesian government. The eighth section examines the ways in which Indonesia has sought to tackle financial aspects of the illicit drug trade. Finally, the last section examines selected decisions of the district courts, the provincial-level High Courts and the Supreme Court, to provide case studies of how the law is actually applied in practice.

The fourth chapter provides a description of narcotics law in Singapore, drawing from legislation, case law, parliamentary speeches, official policy documents, reports, government statistics and academic analysis. It begins with a brief historic account of trading and use of drugs in Singapore before offering an overview of trade and use in contemporary Singapore and the state's response. The second part introduces the legal framework for drug control and describes the main narcotics offences. The third and fourth parts of the chapter examine jurisdictional issues and the various procedural laws that apply to drug-related criminal prosecutions. The fifth section discusses Singapore's legal framework in relation to the rehabilitation of drug users, while the final section describes Singapore's approach to regulating the financial aspects of the illicit drug trade.

The last chapter (the fifth chapter) examines criminal law and practice relevant to the regulation of drug use, cultivation and trade in contemporary socialist Vietnam.It draws on law, policy statements, legal commentary and reports from court, procuracy and ministry websites, the Supreme People's Courts Annual Reports and Vietnamese legal journals to describe criminal law and criminal procedure law relevant to drugs cases. It is also based on interviews with twenty legal professionals, selected judgments and dossiers,and media reporting. Following a brief introduction to the Vietnamese legal system, the patterns of drug use in Vietnam and the history of drug regulation, the chapter describes drugs law and practice in relation to drug offences including: their investigation; evolving presumptions and defendants' rights; the jurisdiction of courts; trial practices; penalties; the appeals processes (including appeal, causational appeals, and the 're-opening' procedure); types of clemency; and death penalty law and practice in Vietnam. It concludes with an account of the role of the media in Vietnamese trials.

Finally, Indonesia, Singapore and Vietnam, have markedly different legal systems and, as a result, divergent criminal laws and practice. These differences are most apparent in criminal procedure and approaches to the death penalty, in both policy and practice. Offering a brief overview of the ways in which these three jurisdictions regulate and practice drug-related law. Begin with substantive offences and then move to investigations, trials, sentencing, and, finally, the death penalty. All the issues 
raised below are covered in more detail in the individual country studies that follow. The aim is simply to demonstrate the diversity of approaches in the three countries, rather than offer a detailed comparative analysis of the three systems.

Overall, this is an important and very interesting book, both for the case studies, and as a clear, considered the cases in three countries. The authors not only take some cases from the District Court and the High Court, but also from the Supreme Court and Constitutional Court in Indonesia and Singapore, while in Vietnam there are only six cases, which are not comparable with other two countries. However, the case studies are entertaining as well as enlightening, and virtually any reader is likely to learn something new from at least one of the cases.

Three jurisdictions were selected because each has experienced controversy over its approach to drugs-related crime in recent years. They also represent different approaches to drug regulation, even though each is seen as adopting a hard line against drug offenders. A comparison of their legal regimes for drugs offences also highlights key differences in practice between civil and common law countries, as well as between liberal and authoritarian states.

It is also beneficial for the readers that the authors include several legislation, such as International Protocols and Convention, Australian, European Union, Indonesian, Nigerian, Singaporean, and Vietnamese legislation which ease the readers to compare and understand the cases well. It is good for the scholars to make this book as a reference because the legal systems of Indonesia, Singapore and Vietnam are, in fact, fundamentally different, so that they can study about the legal framework governing the drugs law in these countries. Despite their differences, legal institutions in the three states selected for study in this book share a common vulnerability to government in influence. In Indonesia, legal institutions, while greatly reformed since Soeharto's fall, are still subject to pressure from political elites, as well as outright corruption. In recent years, however, Indonesia has also become a site of creative litigation, as counsel and activists test the limits of law and the new democratic system through still-emerging and troubled institutions like the Constitutional Court.

Singapore, a tiny former British colony that has become a major East Asian commercial hub, has a sophisticated common law system. Singapore's criminal law is practiced in open court, complete with due process and procedural safeguards, substantial unreviewable power is retained by law enforcement authorities. Vietnam's legal system differs significantly from those of Indonesia and Singapore. Its socialist roots remain strong, particularly in the field of criminal law, and this manifests in the way trials are conducted and how legal institutions relate to each other and their Party leadership. Courts are not independent, although they are now more transparently managed than before 1987.

Despite its virtue, the book is open to a criticism. The author has created the Frameworks for drugs control in Indonesia, Singapore and Vietnam, but it is founded that the authors has done the research only in several cities, especially in Indonesia. The country consists by many big islands, such as Sumatera, Java, Sulawesi, Kalimantan, and Papua, it will be better if the research is conducted in every main island in Indonesia, so the cases will be more comprehensive to be learned.

Yet, the author has included the 6 theories of criminal justice in this book by elaborating the cases. The book has given lots of advantage for the readers, especially the glossary which helps the readers to conceive the content of the book highly. This book is recommended to the scholars, legal practices, academicians, and every person 
who is interested in study the Criminal Law.

Title : Drugs Law and Legal Practice in Southeast Asia

Language : English

Publisher : Bloomsbury

Authors : Pip Nicholson and Tim Lindsey

Pages : 408

Year : 2016

Reviewer : Maskun (Hasanuddin University) 